\title{
Reducing $\mathrm{CO}_{2}$ Flux by Decreasing Tillage in Ohio: Overcoming Conjecture with Data
}

\author{
Deb O’Dell ${ }^{1}$, Neal S. Eash ${ }^{1}$, Bruce B. Hicks ${ }^{2}$, Joel N. Oetting ${ }^{1}$, Thomas J. Sauer ${ }^{3}$, Dayton M. Lambert ${ }^{4}$, \\ Joanne Logan ${ }^{1}$, Wesley C. Wright ${ }^{1} \&$ James A. Zahn ${ }^{5}$ \\ 1 Department of Biosystems Engineering and Soil Science, Institute of Agriculture, University of Tennessee, \\ Knoxville, TN, USA \\ ${ }^{2}$ MetCorps, Norris, TN, USA \\ ${ }^{3}$ United States Department of Agriculture Agricultural Research Service, Ames, Iowa, USA \\ ${ }^{4}$ Department of Agricultural \& Resource Economics, Institute of Agriculture, University of Tennessee, Knoxville, \\ TN, USA \\ ${ }^{5}$ DuPont Tate and Lyle Bio Products, Loudon, TN, USA \\ Correspondence: Deb O’Dell, Department of Biosystems Engineering and Soil Science, Institute of Agriculture, \\ University of Tennessee, Knoxville, TN, USA. Tel: 1-865-384-6073. E-mail: dodell3@utk.edu
}

Received: November 19, 2017

Accepted: December 29, 2017 Online Published: February 15, 2018

doi:10.5539/jas.v10n3p1

URL: https://doi.org/10.5539/jas.v10n3p1

\begin{abstract}
While the literature is clear about excessive tillage decreasing soil carbon $(C)$ content, there are few experimental studies that document the comparative effects of soil and crop management on $\mathrm{C}$ sequestration. Using micrometeorology we measured $\mathrm{CO}_{2}$ flux from a maize crop grown on both no-till and tilled soils in north-central Ohio. We used Bowen Ratio Energy Balance (BREB) systems to quantify the flux between the atmosphere and either the soil surface (at crop planting) or $0.2 \mathrm{~m}$ above the canopy once the crop was established and growing. The no-till plot sequestered $263 \mathrm{~g} \mathrm{CO}_{2} \mathrm{~m}^{-2}(90 \%$ confidence interval -432.1 to -99.9$)$ while the tilled plot emitted $146 \mathrm{~g} \mathrm{CO}_{2} \mathrm{~m}^{-2}$ (90\% confidence interval -53.3 to 332.2) during 104 days of the 2015 growing season; a net difference of $410 \mathrm{~g} \mathrm{CO}_{2} \mathrm{~m}^{-2}$. The difference is statistically significant at the $90 \%$ confidence level (based on a bootstrap analysis). The results indicate that no-tillage practices can sequester $\mathrm{C}$, maintain soil productivity, and ensure landscape sustainability.
\end{abstract}

Keywords: carbon dioxide, $\mathrm{CO}_{2}$ flux, no-till, tillage, carbon sequestration, climate change mitigation, Bowen ratio

\section{Introduction}

The principal sinks for removing $\mathrm{CO}_{2}$ from the atmosphere are usually assumed to be oceans and forests; however, oceans will absorb less $\mathrm{CO}_{2}$ as they warm (Morrison et al., 2015) and forest area is shrinking due to agriculture and other land use changes (FAO, 2016). It has been shown that soil could be a strong sink for atmospheric $\mathrm{CO}_{2}$ (Paustian et al., 2016), partially offsetting increasing global greenhouse gas (GHG) emissions (Tubiello et al., 2015; EPA, 2014; Scripps Institution of Oceanography, 2016). Jenny’s (1941) classic work provides the basis for the collective understanding of the processes by which soils emit and sequester $\mathrm{C}$ through soil-climate-vegetation interactions. These processes depend on many factors including soil type, climate, crop, and agricultural management practices.

While agriculture is a major contributor to increases in GHG emissions, careful implementation of agricultural practices to enhance $\mathrm{C}$ sequestration presents an opportunity to manage soils to mitigate climate change. In particular, the practice of reduced tillage, especially no-till, has been found to reduce $\mathrm{CO}_{2}$ emissions from soils and potentially sequester C (Schlesinger, 1999; West \& Post, 2002; O’Dell et al., 2014). Studies suggest that tillage can influence plant physiology including increased rooting depth from decreased moisture in surface layers of tilled soil (Dwyer et al., 1996) or decreased mechanical resistance (Cox et al., 1990). Other studies indicate that tillage effects on plant physiology may interact with climate as Yu et al. (2016) found that no-till likely increased yield during drought periods by conserving soil moisture. Since arable land represents more than 
$10 \%$ of the global land base (FAO, 2011), arable soils could provide a $\mathrm{C}$ sink to offset fossil fuel emissions (Paustian et al., 2016; Lal, 2004).

Yet recent literature provides a conflicting story of the potential impact of different agricultural practices on soil C. While West and Post (2002) found significant increases in soil organic C (SOC) in the top 7-cm of soil in no-till practices compared to tillage across 67 long-term studies, Vanden Bygaart et al. (2003) and Angers et al. (1997) did not find any differences between no-till and conventional tillage when sampling to a deeper soil depth. Vanden Bygaart and Angers (2006) note the obstacles in comparing measured SOC values due to differences in equivalent soil sampling depth, bulk density, landscape, climate, soil type and experiment duration. Another confounding factor is the lack of a standardized description of tillage, and the variety of related practices used in many research reports. Measurement difficulties also complicate the issue - changes in soil C can take up to a decade to detect if trends are measured using destructive sampling (Smith, 2004). Recently, several publications have been critical of conservation agriculture and no-till because some studies concluded that no-till does not increase $\mathrm{C}$ sequestration or increase crop yields (Baudron et al., 2012) especially in low yield environs common in Sub-Saharan Africa (Cheesman et al., 2016).

Some older research papers and textbooks provide examples of results obtained in the USA showing that tilling enhances $\mathrm{CO}_{2}$ emissions (e.g., Reicosky et al., 1995; Bear, 1953; West \& Marland, 2002). Similarly, recent work found greater $\mathrm{C}$ sequestration with no-till during the crop growing season using BREB in Lesotho and greater no-till sequestration when comparing fallow treatments with cover crops in Zimbabwe (O'Dell et al., 2014; O'Dell et al., 2015). Baker and Griffis (2005) compared the net ecosystem exchange (NEE) of contrasting tillage regimes and cover crops in a maize (Zea mays L.)-soybean (Glycine max L.) rotation using eddy covariance (EC) but found no significant differences in the NEE of strip tillage with a cover crop compared to conventional tillage with no cover crop. Hollinger et al. (2005) reported that maize sequestered C, while soybean emitted C during two years of a six-year maize-soybean rotation EC study. Using EC, Taylor et al. (2013) found that oat (Avena sativa L.) crops grown on fields converted from perennial hay/pasture were net emitters for more than three years while a control hay/pasture field sequestered C.

Many researchers rely on SOC changes by soil depth as the means to determine if $\mathrm{C}$ is being accumulated. Yet without accurate surveying measurements from the bedrock to the soil surface any total SOC estimates will be incomplete and the resulting determinations of changes in accumulated carbon will be questionable. An obvious example could be the subsidence post measuring soil depth from the bedrock at the Everglades Agricultural Area in Belle Glade, FL where oxidation of SOC in a histosol profile has resulted in dramatic soil loss as evidenced by the subsidence post markings (Shih et al., 1998).

Micrometeorological methods including BREB systems and EC provide alternative methodologies for investigating changes in crop and soil carbon inventories. These methods have been used to quantify the differences in $\mathrm{CO}_{2}$ flux between agricultural practices (Dugas et al., 1993; Taylor et al., 2013; O'Dell et al., 2015). The exchange (flux) of $\mathrm{CO}_{2}$ between the surface and the atmosphere can alternatively be measured using static or dynamic chambers. Chamber systems have spatial and temporal challenges somewhat similar to soil sampling (Norman et al., 1997; Davidson et al., 2002; Reicosky, 1997; Reicosky \& Lindstrom, 1995), and are therefore less frequently used in contemporary studies. While the EC and BREB approaches are technically demanding, we believe them to be the optimal approach to evaluate how soil $\mathrm{C}$ sequestration can be manipulated to intensify management impacts. $\mathrm{EC}$ and BREB systems measure the flux of $\mathrm{CO}_{2}$ between the atmosphere and the terrestrial system and by summing this flux, the NEE can be determined for a type of ecosystem over a period of time (Chapin et al., 2006). For the purposes of this paper the term sequestration is used to reflect the capture of atmospheric $\mathrm{CO}_{2}$ by the ecosystem or treatment, e.g., through photosynthesis, while $\mathrm{CO}_{2}$ emissions refers to a release of $\mathrm{CO}_{2}$ by the ecosystem to the atmosphere, such as through respiration. While the ecosystem includes soil, organic matter, plants and other biota, the NEE does not distinguish between the components of the ecosystem. The objective of the present study was to determine tillage effects on $\mathrm{CO}_{2}$ emissions during the maize growing season using the BREB methodology.

\section{Materials and Methods}

\subsection{Site Description}

This study site was in north-central Ohio, USA $\left(40.606^{\circ} \mathrm{N},-82.674^{\circ} \mathrm{W}, 426 \mathrm{~m}\right.$ asl.). Micrometeorological and soil properties were measured from 6 May to 17 August 2015. The soil series on the 9 ha research site are classified as Bennington (fine, illitic, mesic Aeric Epiaqualfs), Amanda (fine-loamy, mixed, active, mesic Typic Hapludalfs), Centerburg (fine-loamy, mixed, active, mesic Aquic Hapludalfs), and Condit (fine, illitic, mesic Typic Epiaqualfs) in USDA Soil Taxonomy (USDA Soil Survey Staff, 1999). The surface soil texture is a silt 
loam and the study site has a slope of $2-6 \%$. The climate is classified as humid continental (Dfb) according to Köppen climate classification, with mean annual rainfall of $955 \mathrm{~mm}$. The study site was managed as an annual row crop production system under no-till for seven years prior to the present study. The prior year's crop was maize.

The study site consisted of two adjacent square plots approximately 4.5 ha each; one plot managed as no-till and the other tilled. A BREB micrometeorological station was erected near the center of each plot. On the no-till plot, maize was planted directly without any tillage except for opening the seed slot (row cleaners were removed). The tilled plot was tandem disked (to manage crop residues), moldboard plowed to a depth of $15 \mathrm{~cm}$, then tandem disked again followed by planting.

Both plots were planted with maize (Zea mays L.) on 8-10 May 2015 at a population density of 84,000 plants $\mathrm{ha}^{-1}$ using 0.76-m rows using a John Deere 7200 6-row Conservation planter. Nitrogen $(\mathrm{N})$ fertilizer was applied to both plots on 3 June 2015 as granular urea (46-0-0) at the rate of $224 \mathrm{~kg} \mathrm{~N} \mathrm{ha}^{-1}$, phosphorus (P) was applied as triple super phosphate $(0-45-0)$ at $112 \mathrm{~kg} \mathrm{P} \mathrm{ha}^{-1}$ and potassium $(\mathrm{K})$ was applied as potash (0-0-60) at $112 \mathrm{~kg} \mathrm{~K}$ ha ${ }^{-1}$ prior to planting.

\subsection{Micrometeorological Measurements and Data Analysis}

Air temperature, vapor pressure and $\mathrm{CO}_{2}$ concentrations were measured before and after planting by the BREB systems, at $0.2-$ and $1.8-\mathrm{m}$ height above the soil or canopy (note: the BREB units were raised incrementally as the maize crop grew, see below). The BREB units had shielded horizontal air intake tubes facing the direction of prevailing winds (west). Temperature was measured with negative temperature coefficient bead type thermistors, vapor pressure was measured with relative humidity probes (model HC2-S3-L, Rotronic, Switzerland supplied by Campbell Scientific, Inc, Logan, UT) and $\mathrm{CO}_{2}$ concentrations were measured with non-dispersive infrared gas analyzers (model LI-820, LI-COR Inc., Lincoln, NE). Five-second sensor data were averaged and recorded every five minutes using a data logger (Model CR3000, Campbell Scientific Inc.). To overcome sensor bias at the two heights, the intake tubes housing the sensors were attached at the end of a centrally mounted rotating arm that swapped the position of the atmospheric sensors every five minutes. To allow for equilibration after sensor rotation, the data logger waited two minutes before collecting 5-s readings in determining the 5-min average. As the crop grew, the BREB temperature, humidity and $\mathrm{CO}_{2}$ sensors were elevated so that the lowest sensor remained about $0.2 \mathrm{~m}$ above the crop canopy, with the height differential $(1.6 \mathrm{~m})$ between sensor intake points remaining constant.

The BREB stations also measured net radiation, soil heat flux, soil temperature, and wind speed. Net radiation was measured with a net radiometer (NR Lite2, Kipp \& Zonen, Delft, The Netherlands), soil heat flux with soil heat flux plates (model HFT3-L, Radiation Energy Balance System (REBS), Seattle, WA) and soil temperatures with four Type "T" thermocouples, two buried at $1.5 \mathrm{~cm}$ and two at $4.5 \mathrm{~cm}$ below the surface. Volumetric soil moisture content was measured $3 \mathrm{~cm}$ below the surface with a water content reflectometer (model CS616, Campbell Scientific, Inc, Logan, UT). Wind direction and speed were measured at the till BREB station with a wind monitor (Model 05305-5, R. M. Young, Inc. Traverse City, MI), and wind speed was measured at the no-till BREB station with a 3-cup anemometer (model 014A, Met One Instruments, Inc., Grants Pass, OR). Rainfall was measured at the no-till BREB station with a tipping bucket rain gauge (model TE525, Texas Electronics, Dallas, TX). Atmospheric pressure was recorded with one silicon altimeter/barometer pressure sensor (model MPX4115, Freescale Semiconductor, Inc., Tempe, AZ). All sensors except thermistors and thermocouples were new and factory-calibrated. Thermistors were created and calibrated in the laboratory; thermocouples were created and calibrated in the field.

Five-second micrometeorological measurements were averaged to calculate 30-min $\mathrm{CO}_{2}$ fluxes according to BREB system theory (Bowen, 1926; Kanemasu et al., 1979; Webb et al., 1980; Held et al., 1990; McGinn \& King, 1990; Dugas, 1993; Perez et al., 1999, Rosenberg et al., 1983) using the following equations as reported by O'Dell et al. (2015). Values of the Bowen ratio $(\beta)$ were derived as:

$$
\beta=\left[P \times C_{P}\left(\Theta_{L}-\Theta_{U}\right)\right] /\left[\lambda \times \varepsilon\left(e_{L}-e_{U}\right)\right]
$$

where, $P$ is measured atmospheric pressure, $C_{p}$ the specific heat capacity of air, $\theta_{L}$ and $\Theta_{U}$ are the potential temperatures calculated from air temperatures measured at lower and upper positions, $\lambda$ the latent heat of vaporization of water, $\varepsilon$ the ratio of the molecular weights of air and water, and $e_{L}$ and $e_{U}$ are the vapor pressures at lower and upper positions.

Latent heat flux, $L E\left(\mathrm{~W} \mathrm{~m}^{-2}\right)$ was calculated as:

$$
L E=\left(R_{n}-G_{0}\right) /(1+\beta)
$$


where, $R_{n}$ is the measured net radiation and $G_{0}$ is the soil heat flux at the soil surface. The correction of soil heat flux for heat storage above the depth of the soil heat flux measurement, $\Delta S$, where, $G_{0}=G_{0.06 \mathrm{~m}}+\Delta S$ was calculated as:

$$
\Delta S=C(\Delta T / \Delta t) z
$$

where, $\Delta S$ is the change in heat storage above the soil heat flux plate, $\mathrm{C}$ the volumetric heat capacity of the soil, $\Delta T$ the change in temperature (current minus previous) of the soil above the heat flux plate taken from average soil temperature measurements at 1.5 and $4.5 \mathrm{~cm}$ depths, $\Delta t$ is the time step (s), $\mathrm{z}$ is the depth of the soil heat flux plate $(6 \mathrm{~cm}) . C$ was calculated (de Vries, 1963) as:

$$
C=C_{m}\left(1-\phi_{f}\right)+C_{w} \times \theta
$$

where, the volumetric heat capacity for dry soil is $C_{m}\left(2.35 \mathrm{MJ} \mathrm{m}^{-3} \mathrm{~K}^{-1}\right.$ (Ochsner et al., 2001)) the volumetric heat capacity of water is $C_{w}\left(4.18 \mathrm{MJ} \mathrm{m}^{-3} \mathrm{~K}^{-1}\right)$, and soil volumetric water content, $\theta$ was based on measurements from soil moisture sensors in both the tilled and untilled plots. Soil porosity, $\phi_{f}$, was calculated as:

$$
\phi_{f}=1-\left(\rho_{b} / \rho_{s}\right)
$$

where, $\rho_{b}$ is soil bulk density, measured at 1.31 and $1.5 \mathrm{Mg} \mathrm{m}^{-3}$ for the till and no-till plots respectively. Soil particle density, $\rho_{s}$, was assumed to be $2.65 \mathrm{Mg} \mathrm{m}^{-3}$.

In practice, two additional terms enter into consideration in the surface energy budget: (a) the storage of heat in the canopy biomass and its water content and (b) the energy used in photosynthesis. Meyers and Hollinger (2004) report a combined influence on the surface energy budget comprising about $15 \%$ of the net radiation for a fully developed maize canopy in daytime. For the Ohio study reported here, canopy biomass was estimated from yield and the harvest index factor for rainfed maize (Djaman et al., 2013). Heat storage in the canopy at the final stage of plant growth at the end of the experiment was found to rarely exceed $1 \%$ of net radiation. The photosynthetic energy used was also estimated to be small, and hence both terms have been omitted from the simple surface energy budget on which the analysis to follow rests. Sensible heat flux, $H\left(\mathrm{~W} \mathrm{~m}^{-2}\right)$ was calculated as:

$$
H=R_{n}-G_{0}-L E
$$

Turbulent diffusivity for sensible heat, $K_{h}\left(\mathrm{~m}^{2} \mathrm{~s}^{-1}\right)$ was calculated as:

$$
K_{h}=\left(H / \rho_{b} C_{p}\right) \times(\Delta z / \Delta \Theta)
$$

where, $\rho_{b} C_{p}$ is the volumetric heat capacity for air, $\Delta z$ is the sensor separation distance $(1.6 \mathrm{~m})$.

The $\mathrm{CO}_{2}$ flux, $A,\left(\mathrm{~kg} \mathrm{~m}^{-2} \mathrm{~s}^{-1}\right)$ was then calculated as:

$$
A=K_{c}\left(\Delta \rho_{c} / \Delta z\right)
$$

where, $K_{c}$ is the turbulent diffusivity for $\mathrm{CO}_{2}\left(\mathrm{~m}^{2} \mathrm{~s}^{-1}\right)$, assumed to be equal to the turbulent diffusivity for sensible heat, and $\Delta \rho_{c}$ is the average difference in $\mathrm{CO}_{2}$ density between measurement heights.

The $\mathrm{CO}_{2}$ flux was corrected for temperature and vapor density differences in terms of latent and sensible heat flux using the following equation (Webb et al., 1980):

$$
A_{\text {corr }}=A+\left(\rho_{c} / \rho_{a}\right) \times\left(0.649 \times 10^{-6} \times L E+3.358 \times 10^{-6} \times H\right)
$$

where, $A_{\text {corr }}$ and $A$ are in $\mathrm{kg} \mathrm{m}^{-2} \mathrm{~s}^{-1}, \rho_{c}$ is the average $\mathrm{CO}_{2}$ density at both measurement heights, $\rho_{a}$ is the density of dry air. In practice, the correction is sufficiently small that its consequences are within the error bounds associated with the measurements made.

As expressed above, the purpose of the study was to explore the role of tillage within the context of $\mathrm{CO}_{2}$ emissions and/or sequestration. In view of the experimental complexity and the unavoidable requirement for continuing instrument maintenance, we limited the study to the crop growth period. Sensor data recording began on 6 May 2015 (before seedling emergence) and extended to 17 August 2015 (crop senescence); therefore the 104-day experimental period encompassed the entire period of crop growth. The sign conventions used in this analysis follow standard micrometeorological practice wherein $\mathrm{CO}_{2}$ flux is positive when $\mathrm{CO}_{2}$ is emitted from the surface and negative when sequestered/absorbed. Data recorded while rain was falling or when sensor failures resulted in incomplete datasets were omitted.

Flux calculations during the night and transition periods (sunrise and sunset, when temperature differences were close to zero) are problematic, resulting in many periods of large uncertainty which produced spikes in calculations of $\mathrm{CO}_{2}$ flux, as also reported elsewhere (e.g., Gilmanov et al., 2003; Massman \& Lee, 2002; Aubinet, 2008; Savage et al., 2009). We utilized an algorithm to remove data spikes in the half-hour $\mathrm{CO}_{2}$ flux data using a median filter similar to that used with eddy covariance data (Papale et al., 2006). The strength in this approach 
lies with the median's resistance to local outliers. While a median filter can distort the flux signal, it is possible to adjust the window width and threshold value as a means to tune the median filter and limit this distortion. This limitation is solved with the use of a median filter extension called the Hampel identifier (Davies \& Gather, 1993; Hampel, 1985). This filter depends on both the window width and an additional tuning parameter: a threshold. If the threshold value is reduced to zero the Hampel identifier functions as a typical median filter and if the threshold approaches infinity the filter effectively becomes an identity filter (Pearson, 1999). The parameters of the Hampel identifier for the two datasets were tuned by trial and error to best exclude outliers. The half width window was chosen to be 5 data points meaning that the window was in total 2.5 hours (five 30-min data points). The threshold value was chosen as 5 . Spikes remaining after the application of the median filter may be a reflection of atmospheric phenomenon or artifacts of the BREB method, especially during night and transition periods.

Once the data spikes were identified they were removed and the data gaps were linearly interpolated. The maximum range of removed and/or missing values interpolated was limited to two hours or less (four 30-min data points). "Absent data" for periods longer than two hours were not interpolated. For consistent comparison, the total sum of $\mathrm{CO}_{2}$ flux was calculated for the period when flux data was available for both till and no-till instruments.

A non-parametric bootstrap procedure (Efron, 1979) was used to determine the variance around the time evolving accumulation of $\mathrm{CO}_{2}$, as described in O'Dell et al. (2015) and was performed with Stata version 14.1 (Stata Corporation, College Station, Texas, USA).

\section{Results and Discussion}

Figure 1 provides graphs showing continual 30-min $\mathrm{CO}_{2}$ flux for each month. During May there were positive $\mathrm{CO}_{2}$ fluxes (emissions) from both the till and no-till plots with greater emissions from the tilled treatment. The tilled plot was plowed on 6 May 2015 (Day of Year (DOY) 126) and planted 8-10 May 2015 (DOY 128-130) and Figure 1 shows positive $\mathrm{CO}_{2}$ fluxes after plowing in May and during the period of emergence. For five days following tillage on DOY 126 the average daytime $\mathrm{CO}_{2}$ flux (between 1000 and $1600 \mathrm{hrs}$ ) for till and no-till were similar in magnitude at $0.61+/-0.03$ and $0.40+/-0.02 \mathrm{~g} \mathrm{CO}_{2} \mathrm{~m}^{-2} \mathrm{hr}^{-1}$ respectively (plus or minus standard error of the mean). During the subsequent five-day period in May (DOY 132-137) $9.1 \mathrm{~mm}$ of rain fell. Whereas before the rainfall the soil temperatures were similar $\left(19.4+/-0.22\right.$ and $19.3+/-0.22{ }^{\circ} \mathrm{C}$ for till and no-till respectively), during the nine-day period (DOY 138-146) following the rainfall soil temperatures averaged over $2{ }^{\circ} \mathrm{C}$ greater in the till than the no-till $\left(17.4+/-0.29\right.$ and $15.2+/-0.20^{\circ} \mathrm{C}$ respectively) due to collective effects of residue cover, albedo and greater evaporative cooling at the soil surface. The average daytime $\mathrm{CO}_{2}$ flux over the tilled plot $\left(0.73+/-0.02 \mathrm{~g} \mathrm{CO}_{2} \mathrm{~m}^{-2} \mathrm{hr}^{-2}\right)$ during this nine-day period following rain was three times greater than over the no-till $\left(0.21+/-0.01 \mathrm{~g} \mathrm{CO}_{2} \mathrm{~m}^{-2} \mathrm{hr}^{-2}\right)$, consistent with expected rates of microbial decomposition (Swift et al., 1979). Greater emission of $\mathrm{CO}_{2}$ is expected following intensive tillage due to aerobic and anaerobic decomposition of exposed organic matter that was occluded in aggregates and unavailable to degradation prior to tillage (Elliott \& Coleman, 1988; Beare et al., 1994; Six et al., 2000). 

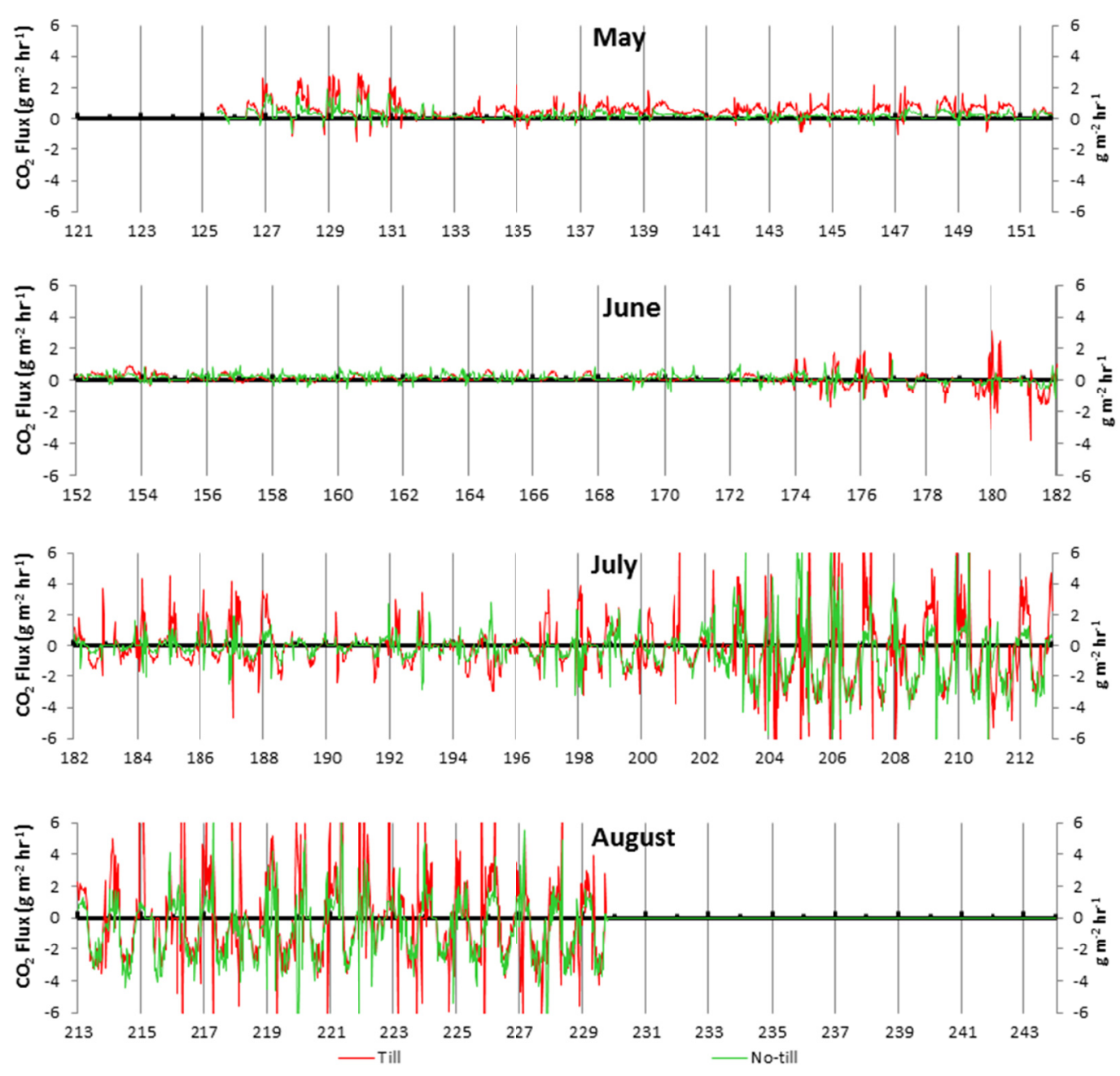

Figure 1. Plots of continual 30-min calculated $\mathrm{CO}_{2}$ flux for each month of the experiment for the till treatment (red) and no-till treatment (green) beginning on 6 May to 17 August 2015 (DOY 126-229)

Figure 2 shows the mean $\mathrm{CO}_{2}$ flux during May by time of day for the till (in red) and no-till (in green) treatments. The mean 30-min $\mathrm{CO}_{2}$ flux by time of day for the till and no-till treatments was then averaged and compared during four distinct periods: daytime between 0900 and $1800 \mathrm{hrs}$, nighttime between 2200 and $0500 \mathrm{hrs}$, the sunrise transition period between 0500 and 0900 and sunset transition period between 1800 and 2200 (Table 1). The mean $\mathrm{CO}_{2}$ flux during each of these periods in May was significantly different when till was compared to no-till using the Student's t-test $(\mathrm{p}<0.01)$. 
Table 1. Mean $\mathrm{CO}_{2}$ flux $\left(\mathrm{g} \mathrm{CO}_{2} \mathrm{~m}^{-2} \mathrm{hr}^{-1}\right)$ for each time of day period by month and treatment, when mean flux was significantly different between treatments according to a t-test $(\mathrm{P}<0.01)$. Mean flux when no significant difference found between treatments are shaded in gray

\begin{tabular}{|c|c|c|c|c|c|c|}
\hline Month & Time Period & Till & No-till & Significant Difference & Net Sequestration & Net Emission \\
\hline \multirow[t]{4}{*}{ May } & Daytime $^{\mathrm{a}}$ & 0.651 & 0.292 & $\mathrm{Y}$ & $\mathrm{N}$ & $\mathrm{Y}$ \\
\hline & Nighttime $^{\mathrm{b}}$ & 0.690 & 0.360 & Y & $\mathrm{N}$ & $\mathrm{Y}$ \\
\hline & Morning Transition ${ }^{c}$ & 0.542 & 0.284 & Y & $\mathrm{N}$ & Y \\
\hline & Evening Transition $^{d}$ & 0.416 & 0.159 & Y & $\mathrm{N}$ & Y \\
\hline \multirow[t]{4}{*}{ June } & Daytime & 0.128 & 0.161 & $\mathrm{~N}$ & $\mathrm{~N}$ & $\mathrm{Y}$ \\
\hline & Nighttime & 0.0841 & 0.179 & $\mathrm{Y}$ & $\mathrm{N}$ & Y \\
\hline & Morning Transition & 0.166 & 0.245 & $\mathrm{~N}$ & $\mathrm{~N}$ & Y \\
\hline & Evening Transition & 0.216 & 0.0624 & Y & $\mathrm{N}$ & Y \\
\hline \multirow[t]{4}{*}{ July } & Daytime & -1.16 & -1.33 & $\mathrm{~N}$ & $\mathrm{Y}$ & $\mathrm{N}$ \\
\hline & Nighttime & 1.04 & 0.412 & $\mathrm{Y}$ & $\mathrm{N}$ & $\mathrm{Y}$ \\
\hline & Morning Transition & 0.451 & -0.017 & Y & $\mathrm{Y}$ & $\mathrm{Y}$ \\
\hline & Evening Transition & 0.171 & -0.116 & Y & Y & Y \\
\hline \multirow[t]{4}{*}{ August } & Daytime & -2.17 & -2.40 & $\bar{Y}$ & $\mathrm{Y}$ & $\mathrm{Y}$ \\
\hline & Nighttime & 2.21 & 0.701 & Y & $\mathrm{N}$ & $\mathrm{Y}$ \\
\hline & Morning Transition & 0.695 & 0.375 & $\mathrm{~N}$ & $\mathrm{~N}$ & $\mathrm{Y}$ \\
\hline & Evening Transition & -0.166 & -0.341 & $\mathrm{~N}$ & $\mathrm{Y}$ & $\mathrm{N}$ \\
\hline
\end{tabular}

Note. ${ }^{\mathrm{a}}$ Daytime hours between 0900 and $1800 ;{ }^{\mathrm{b}}$ Nighttime hours between 2200 and $0500 ;{ }^{\mathrm{c}}$ Morning transition hours between 0500 and 0900; ${ }^{\mathrm{d}}$ Evening transition hours between 1800 and 2200.
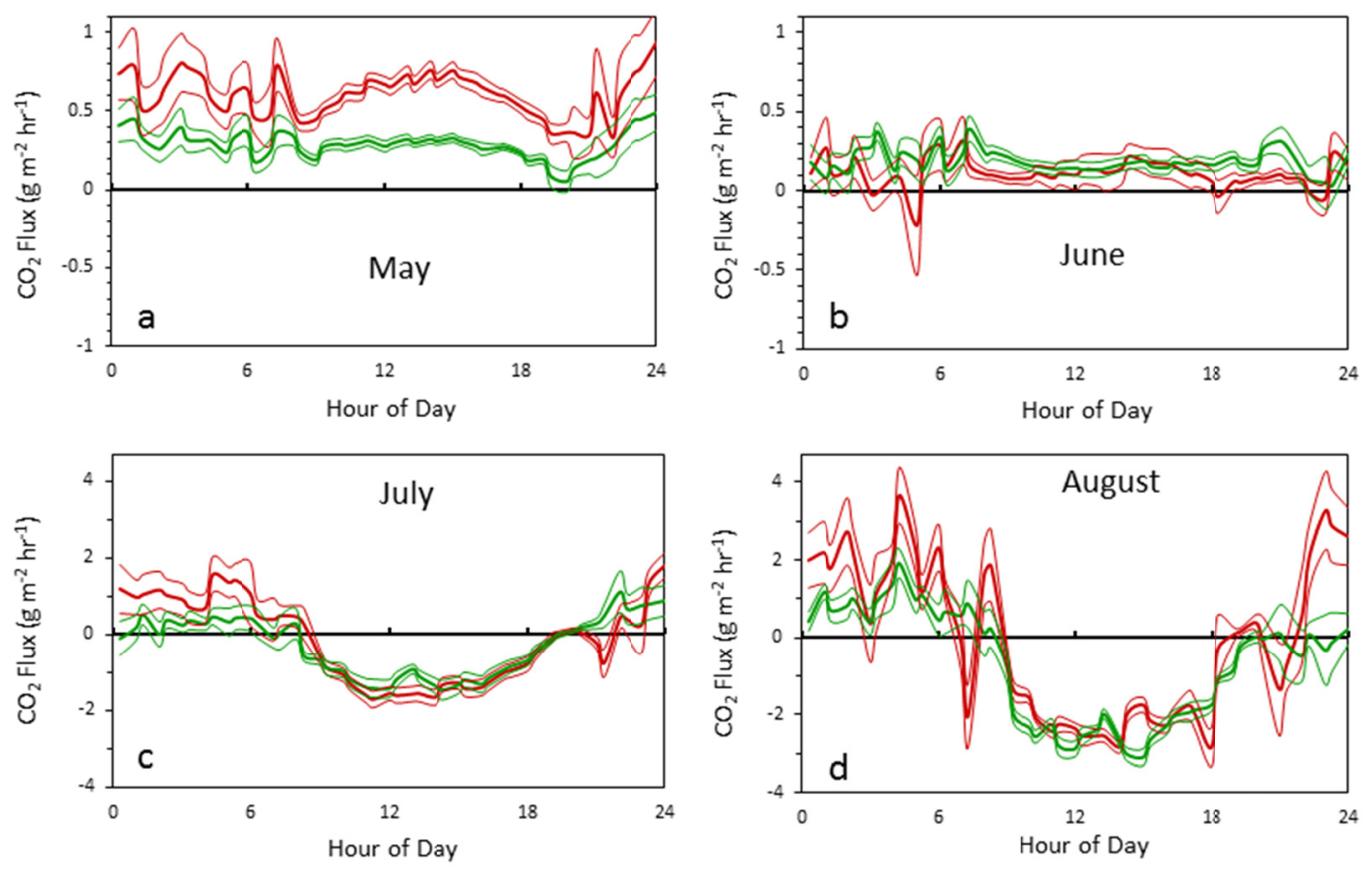

Figure 2. Mean $\mathrm{CO}_{2}$ flux plus/minus one standard error for the till (red) and no-till (green) treatments by time of day for each month

During June the maize plants were approaching exponential growth in biomass. The positive fluxes (emission) measured over both plots began to decrease (Figure 1) and negative fluxes began to appear near the end of June (roughly day 179-182). These trends are especially revealing because of the unusually heavy rainfall-nearly 200 -mm above average rainfall (Table 2). Of the monthly total of $300 \mathrm{~mm}, 232 \mathrm{~mm}$ fell during a ten-day period between June 12-20 (DOY 162-171) (Figure 3). It seems likely that this period of heavy rain resulted in 
denitrification and subsequent $\mathrm{N}$ loss for the cropping season. June was followed by below average rainfall for the rest of the growing season (including periods of drought stress during R1 growth stage).

Table 2. Monthly precipitation measured at experiment site compared to monthly total and 30 year mean recorded at Mansfield Ohio weather station $21.2 \mathrm{~km} \mathrm{NE}$ of experiment site (NOAA National Centers for Environmental Information, 2016)

\begin{tabular}{|c|c|c|c|c|}
\hline & May & June & July & August \\
\hline & \multicolumn{4}{|c|}{----------------------------- $\mathrm{mm}$------------------------- } \\
\hline measured at experiment site & 83.1 & 300 & 93.0 & 27.4 \\
\hline Monthly precipitation at Mansfield, $\mathrm{OH}$ weather station & 112 & 189 & 37.8 & 32.3 \\
\hline 30-year mean monthly precipitation at Mansfield, $\mathrm{OH}$ weather station & 115 & 121 & 111 & 111 \\
\hline
\end{tabular}
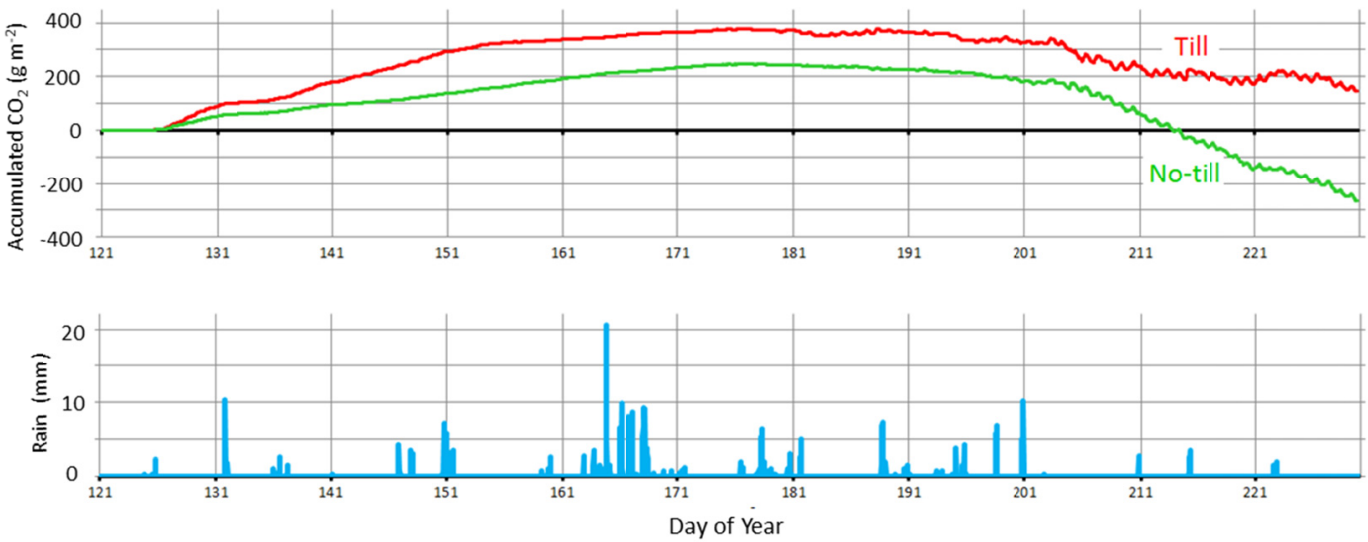

Figure 3 Upper graph is the accumulated sum of $\mathrm{CO}_{2}$ flux for duration of experiment and lower graph is rainfall for the same period

Towards the end of June (DOY 175-181) both plots began to sequester $\mathrm{CO}_{2}$ during the day. The 30-min flux graph for June (Figure 1) shows greater sequestration by the tilled plot than the no-till plot, which corresponded with greener and taller plants. On the whole, during June the no-till plot emitted $98.7 \mathrm{~g} \mathrm{CO}_{2} \mathrm{~m}^{-2}$ while the till emitted 59.2 (Table 3). This was the only month during which the no-till plot emitted more $\mathrm{CO}_{2}$ than the tilled. $\mathrm{CO}_{2}$ flux data for June (Figure 2 and Table 1) show no significant differences between the tilled and no-till treatments, except during the nighttime and evening when the no-till plot emitted more than the tilled.

Table 3. Summation of 30-minute $\mathrm{CO}_{2}$ flux by month and treatment between May 6 and August 17

\begin{tabular}{|c|c|c|c|c|c|}
\hline Treatment & May & June & July & August & Sum of period \\
\hline & \multicolumn{5}{|c|}{ 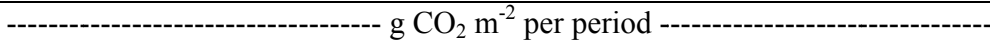 } \\
\hline Till & 300 & 59.2 & -145 & -68.1 & 146 \\
\hline No-till & 141 & 98.7 & -221 & -282 & -263 \\
\hline
\end{tabular}

Rainfall during the experiment was erratic and excessive. June had near record rainfall at the research site that continued into the first half of July (Table 2). As the soils drained and began to dry out there were some days of strong sequestration for both plot treatments, mainly occurring after 22 July 2015 (DOY 203) (see Figure 1). Precipitation measured in the field was 300 and $93.0 \mathrm{~mm}$ for June and July, respectively. The C accumulations during July (Figure 3 ) were flat until after the rains ceased. At that time, sequestration rates paralleled increased crop growth as the crop approached the near exponential growth period. July shows negative $\mathrm{CO}_{2}$ fluxes (Figure 1) during the day with higher emissions at night for the tilled plot (Table 1). Abnormally high rainfall resulted in marginally chlorotic (lighter green color) and shorter maize plants in several rows of both tillage treatments. These observations effectively predicted lower than normal crop productivity. While no-till has many benefits to 
long-term soil health and environmental sustainability, no-till fields are impacted greatly by high rainfall because the soil surface cover prevents the soil from drying which slows soil warming, retards crop growth and development, and enhances denitrification conditions. Linn and Doran (1984) found maximum production of $\mathrm{CO}_{2}$ by soil microbes when the percentage of water-filled pores approached $60 \%$ and they found on average greater percentages of water-filled pores in no-till compared to tilled soils. Greater precipitation during the first part of June likely contributed to greater microbial respiration on the no-till plot during that month.

The BREB stations continued measuring fluxes through August 17 (Figure 1). The mean 30-min $\mathrm{CO}_{2}$ flux graph illustrates large negative daytime fluxes as well as large positive night time fluxes, with the net accumulation being negative for both plots during August (Table 3). Table 1 shows that the crop and soil managed under no-till had on average less emission at night in August and greater sequestration during the day than soils that had been intensively tilled.

Monthly evapotranspiration (ET) was estimated from the BREB latent heat fluxes, calculated as ET $=L E / \lambda$, and was compared with monthly precipitation rates in Table 4, expressed in units of $\mathrm{mm}$ per period. Comparison of monthly ET with rainfall can indicate water availability for crop growth (Díaz-Zorita, et al., 2002; FAO, 1985). During May and June, precipitation exceeded ET; from May through July - the period with the most rain - the tilled ET was greater than no-till ET. During August - when ET was more than double the precipitation - the no-till and tilled ET were similar suggesting that most ET was from canopy transpiration and/or soil moisture conserved by the no-till residue that became available for the final period of crop growth during a dry period. Consistent with evapotranspiration, a comparison of sensible and latent heat flux showed greater latent heat flux for the till treatment and greater sensible heat flux for the no-till during May and June, while differences were not detected during July and August. A comparison of net radiation and soil heat flux did not show discernable differences between the two treatments.

Table 4. Monthly evapotranspiration computed from latent heat flux for each treatment compared with monthly measured precipitation

\begin{tabular}{|c|c|c|c|c|c|}
\hline Treatment & May & June & July & August & Sum of period \\
\hline & \multicolumn{5}{|c|}{------------------------------------------------ $\mathrm{mm}$------------------------------------------- } \\
\hline Monthly precipitation & 82.6 & 300 & 93.0 & 22.1 & 497 \\
\hline Till & 71.3 & 89.4 & 109 & 58.9 & 329 \\
\hline No-till & 49.1 & 62.8 & 97.3 & 58.1 & 267 \\
\hline
\end{tabular}

Average $\mathrm{CO}_{2}$ flux by time of day for each month (Figure 2) summarizes the diurnal flux patterns and their change over time. These graphs show a more consistent and smooth behavior for the daytime hours with greater variability at night, especially for the tilled treatment. During July and August, crop growth dominates the daytime flux resulting in smaller differences between treatments. However following the tillage in May, the tilled plot showed greater soil respiration (emission) than the no-till, a trend that continued through July and August at night. Calculated 30-min fluxes of $\mathrm{CO}_{2}$ were totaled by month and for the period from May 6 through August 17 for the till and no-till plots (Table 3). These calculations show that no-till sequestered $263 \mathrm{~g} \mathrm{CO}_{2} \mathrm{~m}^{-2}$ while the tilled plot emitted $146 \mathrm{~g} \mathrm{CO}_{2} \mathrm{~m}^{-2}$ during the 104 days of measurement, a difference of $410 \mathrm{~g} \mathrm{CO}_{2} \mathrm{~m}^{-2}$.

A rolling bootstrap simulation (Figure 4) was used to estimate the $\mathrm{CO}_{2}$ accumulation variance for each treatment (at $90 \%$ confidence interval). Data for periods when either treatment did not have values for over two hours were removed leaving ca. $75 \%$ of the original data (we also removed the first 10 days to create the initial set for resampling data). The $90 \%$ confidence intervals of the bootstrap distribution are shown in grey (Figure 4 ). The bootstrap accumulation for this 104 day period was $146 \mathrm{~g} \mathrm{CO}_{2} \mathrm{~m}^{-2}$ (90\% confidence interval -53.3 to 332) for the till plot and $-263 \mathrm{~g} \mathrm{CO}_{2} \mathrm{~m}^{-2}$ for the no-till plot (90\% confidence interval -432 to -99.9$)$. 


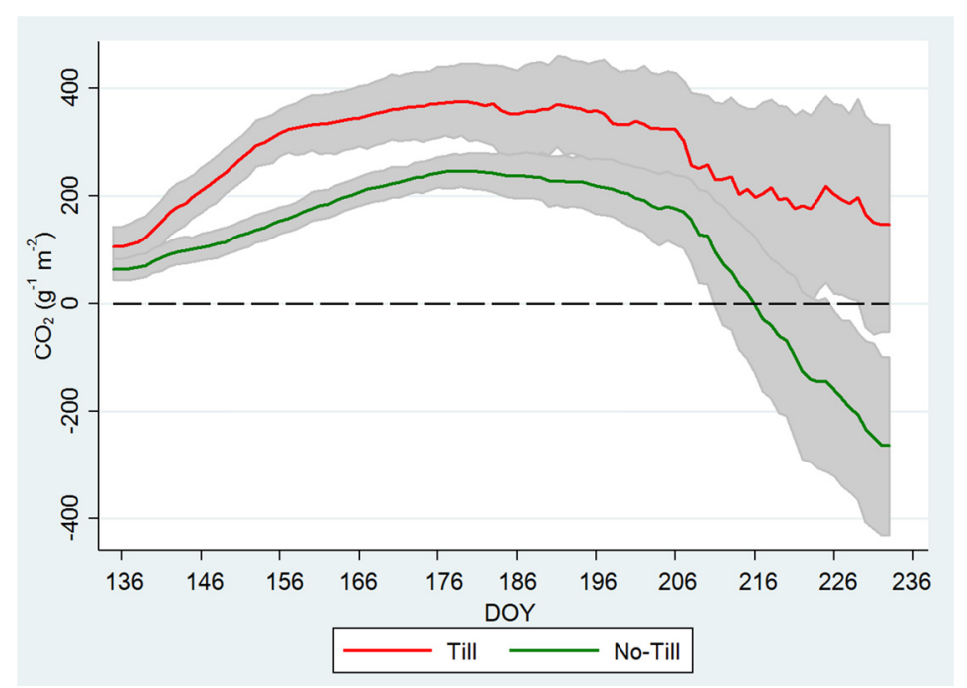

Figure 4. Comparison of accumulated sum of half-hour $\mathrm{CO}_{2}$ for till and no-till plots (shaded areas are $90 \%$ bootstrapped confidence intervals)

The difference in total $\mathrm{CO}_{2}$ flux between the two plots was $410 \mathrm{~g} \mathrm{CO}_{2} \mathrm{~m}^{-2}$ for 104 days. Our results suggest that no-till soil management practices have the potential to sequester $\mathrm{C}$ compared to soil management practices that use intensive tillage. The results also suggest that the extreme rainfall that occurred the year of this study may have lessened the beneficial impact of no-till practices within the context of $\mathrm{CO}_{2}$ sequestration. While there is no such thing as a "normal" year, 2015 was a very wet year at the study site. The major rainfall event (in June (DOY 162-171), as indicated in Figure 3) was followed by a period of very dry weather during pollination that greatly impacted overall yields.

The crop produced below average yield-likely the lowest yields harvested in the recent history of the site - presumably due to above average rainfall in June and below average rainfall in August during the pollination and grainfill periods. Denitrification stunted plants resulting in low ear placement $(<0.3 \mathrm{~m}$ above the soil surface) and excessively high combine header loss due to low ear placement on the maize stalk. An adjacent experiment comparing the combine harvest totals with two hand harvesting methods measured a significantly lower $(\mathrm{p}<0.0001)$ combine harvest yield at $1.70 \mathrm{t} \mathrm{ha}^{-1}$ than both hand harvest methods at $2.75 \mathrm{t} \mathrm{ha}^{-1}$ for a ten-plant method and $2.72 \mathrm{t} \mathrm{ha}^{-1}$ for an in-the-row method (Sullivan, 2016). This adjacent experiment also measured a significantly lower yield $(\mathrm{p}<0.0002)$ for the no-till at $2.17 \mathrm{tha}^{-1}$ compared to $3.26 \mathrm{t} \mathrm{ha}^{-1}$ for the till plot. Despite the lower yield for no-till, there was still some advantage by the no-till practice in sequestering C. In a typical year with greater crop yields and normal rainfall one could expect sequestration rates to be higher. The whole farm maize yield exceeded $14 \mathrm{t} \mathrm{ha}^{-1}$ the following year (2016) with a better rainfall-more normal - pattern.

Studies have shown that surface residue decomposes more slowly than residue incorporated with greater soil contact (Coppens et al., 2004; Noack et al., 2014). Surface residue can act as an insulating barrier reducing soil temperatures and the no-till treatment also may have protected soil $\mathrm{C}$ with lower soil temperatures consistent with studies that found greater $\mathrm{CO}_{2}$ emissions from soil covered with crop residue than from bare soil (Corradi et al., 2013; Al-Kaisi \& Yin, 2005; Fortin et al., 1996). Fortin et al. (1996) showed a correlation between lower soil temperatures and lower $\mathrm{CO}_{2}$ flux for no-till treatment, but this was not found in the present study.

In general, the $\mathrm{CO}_{2}$ fluxes reported here are measurements made above the maize canopy. They represent the consequence of exchange with the soil plus exchange with crop biomass above the surface. If it was assumed that the measured $\mathrm{CO}_{2}$ BREB fluxes at night indicate exchange with the soil, with negligible involvement of the plants (whose stomata are then closed), then it is apparent that the till soil must lose $\mathrm{CO}_{2}$ considerably more rapidly than the no-till. Further, if this increased rate of $\mathrm{CO}_{2}$ loss from the tilled soil continues through the daytime, then the present data would indicate a substantial difference between the accumulation of $\mathrm{CO}_{2}$ by the growing canopies. An estimate of the rate of $\mathrm{CO}_{2}$ accumulation in the growing biomass can be derived by simply subtracting the mean nighttime $\mathrm{CO}_{2}$ flux from the daytime as shown in Table 5. While no more than a first-order approximation, the results show that when the crop is growing most rapidly in July and August, the tilled plot 
accumulated more biomass than the untilled - a conclusion that is compatible with farming expectations that tilling is economically beneficial over the short term.

Table 5. Accumulation rates of $\mathrm{CO}_{2}$ by the canopy assuming that nighttime losses from the soil are representative of the daytime mean fluxes $\left(\mathrm{g} \mathrm{CO}_{2} \mathrm{~m}^{-2} \mathrm{hr}^{-1}\right)$ as shown in Table 1

\begin{tabular}{lllll}
\hline Till & May & June & July & August \\
\hline Daytime flux & 0.651 & 0.128 & -1.16 & -2.17 \\
Nightime flux & 0.69 & 0.084 & 1.04 & 2.21 \\
$\quad$ Excess daytime vs night & -0.039 & 0.044 & -2.2 & -4.38 \\
\hline No-Till & May & June & July & August \\
\hline Daytime flux & 0.292 & 0.161 & -1.33 & -2.4 \\
Nighttime flux & 0.36 & 0.179 & 0.412 & 0.701 \\
$\quad$ Excess daytime vs night & -0.068 & -0.018 & -2.74 & -3.10 \\
\hline
\end{tabular}

The present results indicate that no-till practices can reduce the loss of $\mathrm{CO}_{2}$ from the crop surface during the growing season, when compared with soil tilled after seven years of no-till. When combined with cover crops, it is possible that no-till practices could produce a substantial net annual sequestration of $\mathrm{CO}_{2}$. In the present study tillage resulted in increased $\mathrm{CO}_{2}$ loss from the soil that appears to have continued throughout the study period. Tillage exhumes buried $\mathrm{C}$ sources and provides a means for the soil organisms to mineralize previously occluded organic matter and accelerate decomposition of recently buried crop residue. This study shows that more $\mathrm{CO}_{2}$ flux can be lost from the terrestrial system to the atmosphere during the first year of a transition from a no-till to a conventionally tilled management practice, confirming that tilling increased the decomposition and respiration of crop residues during the growing season resulting in a net $\mathrm{C}$ loss from soils.

In addition to sequestering $\mathrm{C}$, the retention of residues on the soil surface has many positive effects on soil by improving soil aggregation, reducing erosion, and the retention and transport of heat, water and air in the soil (Larson et al., 1978). Though there were periods of high rainfall during the growing season, during drought conditions no-till surface residue can reduce soil moisture loss (Anderson, 2015). While it appears that climate patterns are becoming more erratic and extreme-as evidenced in this study - no-till can be an important management tool to enhance the role of soil in mitigating increased atmospheric $\mathrm{CO}_{2}$ levels. While $\mathrm{C}$ can be sequestered in humid areas under intensive agriculture, sequestering $\mathrm{C}$ in areas with marginal soils and rainfall will likely require that winter cover crops be used to further produce biomass that will be needed if soil C levels are to be improved.

\section{Conclusions}

The present study found that the $\mathrm{CO}_{2}$ flux for a growing season over an experimental tilled plot was $410 \mathrm{~g} \mathrm{CO}_{2}$ $\mathrm{m}^{-2}$ greater than over an adjacent untilled plot. It is recognized that our maize yields were likely affected by excessive precipitation resulting in water-logged soil conditions, $\mathrm{N}$ loss, denitrification and retarded crop growth. Higher emissions under the tilled treatment were likely due to a release of organic matter built up during seven preceding years of no-till practice, as reported in other studies. Subsequent tillage could remove more stored organic matter but would result in lower emissions over time (less new previously occluded organic matter becoming available for mineralization). The ability of no-till to keep the soil cooler may reduce decomposition and preserve soil $\mathrm{C}$ providing a co-benefit in adapting to rising global temperatures. While our maize yields were much less than average yields for this area, our results show that no-till can be an important practice that not only minimizes $\mathrm{C}$ loss from soil but can also be an important tool for sequestering $\mathrm{C}$ in an environment becoming more and more $\mathrm{CO}_{2}$ enriched.

Although the results of this experiment add observational data in support of no-till as a practice to sequester $\mathrm{C}$, more data are needed to understand and quantify these differences under varying climate regimes. To understand the potential magnitude of emissions, factors that impact those emissions, and the overall potential for agriculture to become a recognized climate change mitigant warrants further study. While no-till could reduce $\mathrm{CO}_{2}$ emissions when considering agricultural practices to offset emissions from other sectors, it can only be one small part of an agricultural program that ensures annual net agricultural $\mathrm{C}$ sequestration in high yield environs. Comparative studies of a suite of practices such as the use of cover crops, reduced tillage, and reduced fallow periods are likely necessary to reveal the extent of net soil $\mathrm{C}$ sequestration across a greater range of arable soils. 


\section{Acknowledgements}

The authors wish to acknowledge the University of Tennessee, the US Department of Agriculture, and the National Oceanographic and Atmospheric Administration for instrumentation and support.

\section{References}

Al-Kaisi, M., \& Yin, X. (2005). Tillage and crop residue effects on soil carbon and carbon dioxide emission in corn-soybean rotations. Journal of Environmental Quality, 34(2), 437-445. https://oi.org/10.2134/ jeq2005.0437

Anderson, R. L. (2016). Increasing corn yield with no-till cropping systems: a case study in South Dakota. Renewable Agriculture and Food Systems, 31(6), 568-573. https://doi.org/10.1017/s1742170515000435

Angers, D., Bolinder, M., Carter, M., Gregorich, E., Drury, C., Liang, B., ... Martel, J. (1997). Impact of tillage practices on organic carbon and nitrogen storage in cool, humid soils of eastern Canada. Soil and Tillage Research, 41(3), 191-201. https://doi.org/10.1016/s0167-1987(96)01100-2

Aubinet, M. (2008). Eddy covariance CO2 flux measurements in nocturnal conditions: An analysis of the problem. Ecological Applications, 18(6), 1368-1378. https://doi.org/10.1890/06-1336.1

Baker, J., \& Griffis, T. (2005). Examining strategies to improve the carbon balance of corn/soybean agriculture using eddy covariance and mass balance techniques. Agricultural and Forest Meteorology, 128(3), $163-177$. https://doi.org/10.1016/j.agrformet.2004.11.005

Baudron, F., Tittonell, P., Corbeels, M., Letourmy, P., \& Giller, K. (2011). Comparative performance of conservation agriculture and current smallholder farming practices in semi-arid Zimbabwe. Field Crops Research, 132, 117-128. https://doi.org/10.1016/j.fcr.2011.09.008

Bear, F. E. (1953). Soils and fertilizers (4th ed.). New York: John Wiley and Sons, Inc.

Beare, M., Hendrix, P., Cabrera, M., \& Coleman, D. (1994). Aggregate-protected and unprotected organic matter pools in conventional-and no-tillage soils. Soil Science Society of America Journal, 58(3), 787-795. https://doi.org/10.2136/sssaj1994.03615995005800030021x

Bowen, I. (1926). The ratio of heat losses by conduction and by evaporation from any water surface. Physical Review, 27(6), 779. https://doi.org/10.1103/physrev.27.779

Chapin, F. S., Woodwell, G. M., Randerson, J. T., Rastetter, E. B., Lovett, G. M., Baldocchi, D. D., ... Wirth, C. (2006). Reconciling Carbon-cycle Concepts, Terminology, and Methods. Ecosystems, 9(7), 1041-1050. https://doi.org/10.1007/s10021-005-0105-7

Cheesman, S., Thierfelder, C., Eash, N.S., Kassie, G. T., \& Frossard, E. (2016). Soil carbon stocks in conservation agriculture systems of Southern Africa. Soil and Tillage Research, 156, 99-109. https://doi.org/10.1016/j.still.2015.09.018

Coppens, F., Garnier, P. F., Merckx, R., \& Recous, S. (2004). Decomposition of mulched versus incorporated crop residues: modelling with PASTIS clarifies interactions between residue quality and location. Soil Biology and Biochemistry, 39(9), 2339-2350. https://doi.org/10.1016/j.soilbio.2007.04.005

Corradi, M., Panosso, A., Martins Filho, M., \& La Scala Junior, N. (2013). Crop residues on short-term CO2 emissions in sugarcane production areas. Engenharia Agrícola, 33(4), 699-708. https://doi.org/10.1590/ S0100-69162013000400009

Cox, W., Zobel, R., Van Es, H., \& Otis, D. (1990). Tillage effects on some soil physical and corn physiological characteristics. Agron. J., 82, 806-812. https://doi.org/10.2134/agronj1990.00021962008200040030x

Davidson, E., Savage, K., Verchot, L., \& Navarro, R. (2002). Minimizing artifacts and biases in chamber-based measurements of soil respiration. Agricultural and Forest Meteorology, 113(1), 21-37. https://doi.org/ 10.1016/s0168-1923(02)00100-4

Davies, L., \& Gather, U. (1993). The identification of multiple outliers. Journal of the American Statistical Association, 88(423), 782-792. https://doi.org/10.2307/2290763

de Vries, D. (1963). Thermal properties of soils. In W. R. van. Wijk (Ed.), Physics of plant environment (pp. 210-235). Amsterdam: North-Holland Publ. Co.

Díaz-Zorita, M., Duarte, G., \& Grove, J. (2002). A review of no-till systems and soil management for sustainable crop production in the subhumid and semiarid Pampas of Argentina. Soil and Tillage Research, 65(1), 1-18. https://doi.org/10.1016/s0167-1987(01)00274-4 
Djaman, K., Irmak, S., Rathje, W., Martin, D., \& Eisenhauer, D. (2013). Maize evapotranspiration, yield production functions, biomass, grain yield, harvest index, and yield response factors under full and limited irrigation. Transactions of the ASABE, 56(2), 373-393. https://doi.org/10.13031/2013.42676

Dugas, W. A. (1993). Micrometeorological and chamber measurements of CO2 flux from bare soil. Agricultural and Forest Meteorology, 67, 115-128. https://doi.org/10.1016/0168-1923(93)90053-K

Dwyer, L., Ma, B., Stewart, D., Hayhoe, H., Balchin, D., Culley, J., \& McGovem, M. (1996). Root mass distribution under conventional and conservation tillage. Canadian Journal of Soil Science, 76, 23-28. https://doi.org/10.4141/cjss96-004

Efron, B. (1979). Bootstrap methods: Another look at the jackknife. Annals of Statistics, 7, 1-26. https://doi.org/10.1214/aos/1176344552

Elliott, E., \& Coleman, D. (1988). Let the soil work for us. Ecological Bulletins, 39, 23-32.

EPA. (2014). Inventory of U.S. Greenhouse Gas Emissions and Sinks: 1990-2012. Washington, D.C.: U.S. Environmental Protection Agency.

FAO. (1985). Agroclimatological data for Latin America and the Caribbean (FAO Production and Protection Series ed.). Rome: FAO.

FAO. (2011). FAOSTAT \% of Agricultural area/land area. Retrieved May 14, 2016, from http://faostat3.fao.org/ download/E/EL/E

FAO. (2016). Global Forest Resources Assessments. Retrieved May 13, 2016, from http://www.fao.org/forestresources-assessment/en

Fortin, M., Rochette, P., \& Pattey, E. (1996). Soil carbon dioxide fluxes from conventional and no-tillage small-grain cropping systems. Soil Science Society of America Journal, 60(5), 1541-1547. https://doi.org/ 10.2136/sssaj1996.03615995006000050036x

Hampel, F. (1985). The Breakdown Points of the Mean Combined With Some Rejection Rules. Technometrics, 27, 95-107. https://doi.org/10.1080/00401706.1985.10488027

Held, A. A., Steduto, P., Orgaz, F., Matista, A., \& Hsiao, T. C. (1990). Bowen ratio/energy balance technique for estimating crop net $\mathrm{CO} 2$ assimilation, and comparison with a canopy chamber. Theor. Appl. Climatol., 42, 203-213. https://doi.org/10.1007/bf00865980

Hollinger, S., Bernacchi, C., \& Meyers, T. (2005). Carbon budget of mature no-till ecosystem in North Central Region of the United States. Agricultural and Forest Meteorology, 130(1), 59-69. https://doi.org/10.1016/ j.agrformet.2005.01.005

Jenny, H. (1941). Factors of soil formation: a system of quantitative pedology. New York: McGraw-Hill.

Kanemasu, E. T., Wesely, M. L., Hicks, B. B., \& Heilman, J. L. (1979). Techniques for calculating energy and mass fluxes. In B. J. Barfield \& J. F. Gerber (Eds.), Modification of the Aerial Environment of Crops (pp. 156-182). St. Joseph, MI: American Society of Agricultural and Biological Engineers.

Lal, R. (2004). Soil carbon sequestration impacts on global climate change and food security. Science, 304(5677), 1623-1627. https://doi.org/10.1126/science.1097396

Larson, W., Holt, R., \& Carlson, C. (1978). Residues for soil conservation. Crop residue management systems. In W. R. Oschwald (Ed.), Crop Residue Management Systems (pp. 1-15). Madison: ASA, CSSA, and SSSA. https://doi.org/10.2134/asaspecpub31.c1

Linn, D., \& Doran, J. (1984). Effect of water-filled pore space on carbon dioxide and nitrous oxide production in tilled and nontilled soils. Soil Science Society of America Journal, 48(6), 1267-1272. https://doi.org/ 10.2136/sssaj1984.03615995004800060013x

McGinn, S. M., \& King, K. M. (1990). Simultaneous measurements of heat, water vapour and CO2 fluxes above alfalfa and maize. Agric. For. Meteorol., 49, 331-349. https://doi.org/10.1016/0168-1923(90)90005-q

Meyers, T., \& Hollinger, S. (2004). An assessment of storage terms in the surface energy balance of maize and soybean. Agricultural and Forest Meteorology, 125(1), 105-115. https://doi.org/10.1016/j.agrformet. 2004.03.001

Morrison, A., Frölicher, T., \& Sarmiento, J. (2015). Upwelling in the Southern Ocean. Physics Today, $68(1), 27$. https://doi.org/10.1063/PT.3.2654 
Noack, S., McBeath, T., McLaughlin, M., Smernik, R., \& Armstrong, R. (2014). Management of crop residues affects the transfer of phosphorus to plant and soil pools: Results from a dual-labelling experiment. Soil Biology and Biochemistry, 71, 31-39. https://doi.org/10.1016/j.soilbio.2013.12.022

Norman, J., Kucharik, C., Gower, S., Baldocchi, D., Crill, P., Rayment, M., ... Strieglfi, R. (1997). A comparison of six methods for measuring soil-surface carbon dioxide fluxes. Journal of Geophysical Research, 103(D24), 28-771. https://doi.org/10.1029/97jd01440

O’Dell, D., Sauer, T. J., Hicks, B. B., Thierfelder, C., Lambert, D. M., Logan, J., \& Eash, N. S. (2015). A short-term assessment of carbon dioxide fluxes under contrasting agricultural and soil management practices in Zimbabwe. Journal of Agricultural Science, 7(3), 32-48. https://doi.org/10.5539/jas.v7n3p32

O’Dell, D., Sauer, T., Hicks, B., Lambert, D., Smith, D., Bruns, W., ... Eash, N. (2014). Bowen Ratio Energy Balance Measurement of Carbon Dioxide $\left(\mathrm{CO}_{2}\right)$ Fluxes of No-Till and Conventional Tillage Agriculture in Lesotho. Open Journal of Soil Science, 4(3), Article ID: 43617. https://doi.org/10.4236/ojss.2014.43012

Ochsner, T., Horton, R., \& Ren, T. (2001). A new perspective on soil thermal properties. Soil science society of America Journal, 65(6), 1641-1647. https://doi.org/10.2136/sssaj2001.1641

Papale, D., Reichstein, M., Aubinet, M., Canfora, E., Bernhofer, C., Kutsch, W., ... Yakir, D. (2006). Towards a standardized processing of Net Ecosystem Exchange measured with eddy covariance technique: Algorithms and uncertainty estimation. Biogeosciences, 3(4), 571-583. https://doi.org/10.5194/bg-3-571-2006

Paustian, K., Lehmann, J., Ogle, S., Reay, D., Robertson, G., \& Smith, P. (2016). Climate-smart soils. Nature, 532(7597), 49-57. https://doi.org/10.1038/nature17174

Pearson, R. (1999). Data cleaning for dynamic modeling and control. Karlsruhe: European Control Conference.

Perez, P. J., Castellvi, F., Ibanez, M., \& Rosell, J. I. (1999). Assessment of reliability of Bowen ratio method for partitioning fluxes. Agric. For. Meteorol., 97, 141-150. https://doi.org/10.1016/s0168-1923(99)00080-5

Reicosky, D. (1997). Tillage-induced $\mathrm{CO}_{2}$ emission from soil. Nutrient Cycling in Agroecosystems, 1(3), 273-285. https://doi.org/10.1023/A:1009766510274

Reicosky, D., \& Lindstrom, M. (1995). Impact of fall tillage on short-term carbon dioxide flux. In L. Rattan, J. Kimble, E. Levine, \& B. Stewart (Eds.), Soil and Global Change (pp. 177-187). Chelsea, Michigan: Lewis Publishers.

Reicosky, D., Kemper, W., Langdale, G., Douglas, C., \& Rasmussen, P. (1995). Soil organic matter changes resulting from tillage and biomass production. Journal of Soil and Water Conservation, 50(3), 253-261.

Rosenberg, N., Blad, B., \& Verma, S. (1983). Microclimate: The Biological Environment. New York: John Wiley \& Sons.

Savage, M., Everson, C., \& Metelerkamp, B. (2009). Bowen ratio evaporation measurement in a remote montane grassland: Data integrity and fluxes. Journal of Hydrology, 376(1), 249-260. https://doi.org/10.1016/ j.jhydrol.2009.07.038

Schlesinger, W. H. (1999). Carbon sequestration in soils. Science, 284, 2095. https://doi.org/10.1126/ science. 284.5423 .2095

Scripps Institution of Oceanography. (2016). Scripps CO2 Program: The Keeling Curve. Retrieved August 10, 2016, from https://scripps.ucsd.edu/programs/keelingcurve

Shih, S., Glaz, B., \& Barnes Jr., R. (1998). Subsidence of organic soils in the Everglades Agricultural Area during the past 19 years. Soil Crop Sci. Soc., 57, 20-29.

Six, J., Elliott, E., \& Paustian, K. (2000). Soil macroaggregate turnover and microaggregate formation: A mechanism for $\mathrm{C}$ sequestration under no-tillage agriculture. Soil Biology and Biochemistry, 32(14), 2099-2103. https://doi.org/10.1016/s0038-0717(00)00179-6

Smith, P. (2004). How long before a change in soil organic carbon can be detected? Global Change Biology, 10(11), 1878-1883. https://doi.org/10.1111/j.1365-2486.2004.00854.X

Stephens, J., \& Johnson, L. (1951). Subsidence of organic soils in the upper Everglades region of Florida. Soil Sci. Soc., 11, 191-237. https://doi.org/10.2136/sssaj1956.03615995002000010019x

Sullivan, C. (2016). Contrasting Soil Management Practice, Nitrogen Source, and Harvest Method Effects on Corn Production in Ohio and Tennessee. Knoxville: University of Tennessee. 
Swift, M., Heal, O., \& Anderson, J. (1979). Decomposition in terrestrial ecosystems. London: Blackwell.

Taylor, A., Amiro, B., \& Fraser, T. (2013). Net $\mathrm{CO}_{2}$ exchange and carbon budgets of a three-year crop rotation following conversion of perennial lands to annual cropping in Manitoba, Canada. Agricultural and Forest Meteorology, 182, 67-75. https://doi.org/10.1016/j.agrformet.2013.07.008

Tubiello, F., Salvatore, M., Ferrara, A., House, J., Federici, S., Rossi, S., ... Prosperi, P. (2015). The contribution of agriculture, forestry and other land use activities to global warming. Global Change Biology, 21(7), 2655-2660. https://doi.org/10.1111/gcb.12865

USDA Soil Survey Staff. (1999). Soil taxonomy: A basic system of soil classification for making and interpreting soil surveys. Soil Taxonomy (2nd ed.) Retrieved May 31, 2014, from http://www.nrcs.usda.gov/ $\mathrm{wps} / \mathrm{portal} / \mathrm{nrcs} / \mathrm{main} /$ soils/survey/class/taxonomy/

Vanden Bygaart, A., \& Angers, D. (2006). Towards accurate measurements of soil organic carbon stock change in agroecosystems. Canadian Journal of Soil Science, 86(3), 465-471. https://doi.org/10.4141/s05-106

Vanden Bygaart, A., Gregorich, E., \& Angers, D. (2003). Influence of agricultural management on soil organic carbon: A compendium and assessment of Canadian studies. Canadian Journal of Soil Science, 83(4), 363-380. https://doi.org/10.4141/s03-009

Webb, E. K., Pearman, G. I., \& Leuning, R. (1980). Correction of flux measurements for density effects due to heat and water vapour transfer. Quart. J. R. Met. Soc., 106, 85-100. https://doi.org/10.1002/qj.49710644707

West, T. O., \& Marland, G. (2002). A synthesis of carbon sequestration, carbon emissions, and net carbon flux in agriculture: Comparing tillage practices in the United States. Agriculture, Ecosystems \& Environment, 91(1), 217-232. https://doi.org/10.1016/s0167-8809(01)00233-X

West, T. O., \& Post, W. M. (2002). Soil organic carbon sequestration rates. Soil Science Society of America Journal, 66(6), 1930-1946. https://doi.org/10.2136/sssaj2002.1930

Yu, C., Hui, D., Deng, Q., Wang, J., Reddy, K., \& Dennis, S. (2016). Responses of corn physiology and yield to six agricultural practices over three years in middle Tennessee. Scientific Reports, 6, 27504. https://doi.org/10.1038/srep27504

\section{Copyrights}

Copyright for this article is retained by the author(s), with first publication rights granted to the journal.

This is an open-access article distributed under the terms and conditions of the Creative Commons Attribution license (http://creativecommons.org/licenses/by/4.0/). 